\title{
Implementasi Asas Ius Curia Novit Dalam Penafsiran Hukum Putusan Hakim Tentang Keabsahan Penetapan Tersangka
}

\author{
Yuristyawan Pambudi Wicaksana \\ yuriswicaksana@gmail.com
}

\begin{abstract}
This study examined the application of ius curia novit principle in the legal interpretation of the verdicts made by a pretrial single judge who examines the validity of suspect status determination, which is obviously observable from the Decision of the District Court as the first and last dispute settler. This research was of doctrinal type with a legal regulation approach. Of the verdicts of the District Court that adjudicated pretrial cases, some verdicts only examined formal matters or prioritize objective elements that were limited to administrative issues settled by investigators. On the other hand, several verdicts were more valiant to examine subjective elements, including considering the quality of the completed examination. This means that disparity remains to exist in the verdicts when judges examine the validity of suspect status determination. In the future, therefore, to actualize the equality of legal opinions and the uniformity of legal framework objectively, it is important to rearrange the pretrial of suspect status determination based on the Criminal Procedure Code.
\end{abstract}

Keywords: Ius curia novit principle; pretrial of suspect status determination; legal interpretation

\begin{abstract}
Abstrak
Penelitian ini mengkaji penerapan asas ius curia novit dalam penafsiran hukum putusan-putusan hakim tunggal praperadilan yang memeriksa keabsahan penetapan seseorang sebagai tersangka yang sangat kentara terlihat dari Putusan Pengadilan Negeri tingkat pertama sebagai pemutus sengketa pertama dan terakhir. Penelitian ini termasuk ke dalam tipe penelitian doktrinal dengan pendekatan peraturan perundangundangan. Penelitian ini menyimpulkan, di antara putusan-putusan Pengadilan Negeri yang mengadili perkara praperadilan ada putusan yang hanya menguji hal-hal yang bersifat formal atau yang mengedepankan unsur obyektif yaitu sebatas masalah administrasi yang telah dilakukan oleh penyidik, di sisi lain juga terdapat putusan yang lebih berani masuk ke dalam unsur subjektif yaitu termasuk pula mempertimbangkan mengenai kualitas pemeriksaan yang telah dilakukan. Artinya masih terdapat disparitas putusan hakim dalam menguji sah tidaknya penetapan tersangka. Karena itu, ke depan, untuk mewujudkan terciptanya kesamaan pendapat hukum dan keseragaman kerangka kerja hukum secara objektif, perlu pengaturan kembali terkait praperadilan penetapan tersangka berdasarkan pada Hukum Acara Pidana.
\end{abstract}

Kata-kata Kunci: Asas ius curia novit; praperadilan penetapan tersangka; penafsiran hukum 


\section{Pendahuluan}

Terbukanya kesempatan bagi para tersangka untuk menguji keabsahan penetapan dirinya dalam pranata praperadilan ternyata masih menuai suatu masalah. Pasca keluarnya Putusan Mahkamah Konstitusi No. 21/PUU-XII/2014 pada 28 April 2015, ternyata tidak diikuti dengan aturan pelaksanaan serta mekanisme yang jelas bagi hakim tunggal praperadilan yang akan memeriksa perkara. Hal ini karena tidak seperti dalam perubahan undang-undang yang juga memuat penjelasan pasal-perpasal serta kemungkinan petunjuk pelaksanaan diatur dalam peraturan perundang-undangan yang lebih lengkap. Mahkamah Konstitusi tampaknya lebih memberikan ruang yang luas bagi hakim untuk memberikan penafsiran hukum bagi "kekurangjelasan" akibat dari amar putusannya sendiri.

Dampak yang ditimbulkan dari kekurangjelasan aturan dalam pemeriksaan sah tidaknya penetapan seseorang sebagai tersangka yaitu adanya berbagai penafsiran yang berbeda antara penegak hukum. Perbedaan penafsiran yang timbul baik itu oleh hakim, jaksa penuntut umum maupun advokat menyebabkan masing-masing memiliki kriterianya sendiri yang tidak jarang bertentangan satu dan lainnya tentang suatu penetapan tersangka yang dapat dibatalkan menurut hukum. Mahkamah Agung sendiri sebagai induk peradilan umum hingga kini belum memberikan pedoman terkait pemeriksaan permohonan praperadilan penetapan tersangka, bahkan menyerahkan sepenuhnya proses tersebut kepada hakim tunggal pemeriksa perkara praperadilan di pengadilan tingkat pertama.

Terbukanya ruang penafsiran yang bergitu lebar serta tanpa adanya pedoman baku tersebut akan problematis ketika dibenturkan dengan Asas Ius Curia Novit yang diturunkan dari Pasal 5 ayat (1) Undang-Undang No. 48 Tahun 2009 tentang Kekuasaan Kehakiman, yang artinya penafsir tunggal terletak pada satu orang hakim. ${ }^{1}$ Hakim sebagai pemberi putusan akhir dipandang tahu akan hukum sehingga tidak boleh menolak perkara karena ketidakjelasan aturan. ${ }^{2}$ Sebaliknya,

${ }^{1}$ Untuk selanjutnya disingkat Undang-Undang Kekuasaan Kehakiman.

2 M. Natsir Asnawi, Hermeneutika Putusan Hakim, Cetakan Pertama, UII Press, Yogyakarta, 2014, hlm. 17. 
harus tetap memberikan putusan dengan menggali, mengikuti dan memahamai nilai hukum dan rasa keadilan yang hidup dalam masyarakat. ${ }^{3}$ Pada saat yang bersamaan putusan praperadilan juga merupakan putusan akhir yang final dan mengikat karena tidak dapat dilakukan upaya hukum banding sebagaimana dilarang dalam Pasal 83 KUHAP serta Putusan Mahkamah Konstitusi No. 65/PUU-IX/2011. Larangan untuk diajukan Kasasi terdapat dalam Pasal 45A Undang-Undang No. 5 Tahun 2004 tentang Perubahan Pertama Undang-Undang No. 14 Tahun 1985 tentang Mahkamah Agung. Sedangkan larangan untuk Peninjauan Kembali diatur dalam Peraturan Mahkamah Agung No. 4 Tahun 2016 tentang Larangan Peninjauan Kembali Putusan Praperadilan. Oleh karena itu, penelitian ini akan mengkaji penerapan Asas ius curia novit dalam putusan-putusan hakim tunggal praperadilan yang memeriksa mengenai keabsahan penetapan seseorang sebagai tersangka.

\section{Rumusan Masalah}

Bagaimana implementasi asas ius curia novit dalam penafsiran hukum yang terkandung dalam putusan hakim tentang keabsahan penetapan seseorang sebagai tersangka?

\section{Tujuan Penelitian}

Mengetahui implementasi asas ius curia novit dalam penafsiran hukum yang terkandung dalam putusan hakim tentang keabsahan penetapan seseorang sebagai tersangka.

\section{Metode Penelitian}

Penelitian ini termasuk ke dalam tipe kajian Ajaran Hukum Murni yang mengkaji "law as it written in the books", dengan demikian metode yang digunakan adalah metode doktrinal atau metode pendekatan yuridis normatif, yaitu pendekatan dari sudut pandang ketentuan hukum atau peraturan perundang-

${ }^{3}$ H.A. Mukhsin Asyrof, "Asas-Asas Penemuan Hukum dan Penciptaan Hukum oleh Hakim dalam Proses Peradilan”, Varia Peradilan, Edisi No. 252 Ke-XXI, November 2006, hlm. 84.

${ }^{4}$ Bernard Arief Sidharta, Refleksi tentang Struktur Ilmu Hukum, Mandar Maju, Bandung, 2009, hlm. 158. 
undangan yang berlaku. ${ }^{5}$ Hukum lazimnya diartikan kaidah atau norma, dapat pula diartikan keputusan pejabat seperti putusan hakim. ${ }^{6}$ Sumber hukum yang digunakan yaitu sumber hukum primer berupa peraturan perundang undangan dan putusan pengadilan, dan sumber hukum sekunder berupa buku, jurnal, dan hasil penelitian terdahulu yang sejenis. Analisis data yang digunakan dalam penelitian ini adalah analisis data kualitatif, yaitu lebih menekankan uraianya secara naratif dan tidak didasarkan pada data numerikal (angka), tidak mengenal populasi dan sampling serta sarat berisi nilai-nilai. ${ }^{7}$ Analisis yang bersifat yuridis kualitatif juga sangat membantu dalam proses memilih, mengelompokkan, membandingkan, mensintesakan, dan menafsirkan secara sistematis guna mencari penjelasan dari fenomena yang sedang diteliti. ${ }^{8}$

\section{Hasil Penelitian dan Pembahasan}

\section{Asas Ius Curia Novit dalam Penafsiran Hukum Putusan Hakim tentang Keabsahan Penetapan Seseorang Sebagai Tersangka}

Asas Ius Curia Novit memandang bahwa setiap hakim tahu akan hukum sehingga harus mengadili setiap perkara yang diajukan kepadanya. Asas ini pertama kali ditemukan dalam tulisan-tulisan para ahli hukum abad pertengahan (glossators) tentang hukum romawi kuno. ${ }^{9}$ Ius Curia Novit adalah prinsip yang memandang bahwa "hakim tahu akan hukumnya" (the court knows the law). Karena itu, kewajiban seorang hakimlah yang menentukan hukum apa yang harus diberlakukan terhadap kasus tertentu dan bagaimana penerapannya. Asas ini telah lama dikenal dalam sistem Civil Law sehingga para pihak bersengketa tidak perlu mendalilkan atau membuktikan hukum yang berlaku untuk kasus mereka karena hakim dipandang tahu akan hukumnya. Sebaliknya, di dalam sistem Common Law asas ini tidak dikenal, para pihaklah yang harus mendalilkan hukum yang berlaku,

5 Pedoman Penyusunan Tugas Akhir, Fakulas Hukum UII, Yogyakarta, 2008, hlm. 14.

${ }^{6}$ Beni Ahmad Saebani, Metode Penelitian Hukum, Pustaka Setia, Bandung, 2008, hlm. 32.

7 Ahmad Fikri Hadin, Penelitian Hukum Indonesia Kontemporer, Cetakan Pertama, Genta Publishing, Yogyakarta, 2012, hlm. 23.

${ }^{8}$ Lilik Mulyadi, Hukum Pidana Adat Kajian Asas, Teori, Norma, Praktik dan Prosedur, Alumni, Bandung, 2015, hlm. 39.

9 Miftakhul Huda, "Ius Curia Novit", dalam http://www.miftakhulhuda.com/2011/02/ius-curianovit.html, Akses 20 Januari 2017. 
apakah sesuai atau bertentangan dengan yurisprudensi harus disampaikan dan dijelaskan di hadapan hakim. ${ }^{10}$

Secara historis, Asas ius curia novit yang dikenal dalam sistem hukum Civil Law, berasal dari kaum legisme yaitu aliran hukum yang menganggap satusatunya yang merupakan hukum adalah undang-undang dan tidak ada lagi hukum selain itu. ${ }^{11}$ Pada masa itu seluruh hukum yang berlaku telah terkodifikasi secara lengkap dalam suatu kitab undang-undang sehingga mempermudah para hakim untuk mencari hukum yang sesuai dengan fakta yang diajukan oleh pihak bersengketa, terlebih undang-undang di suatu negara pada waktu itu tidak sebanyak seperti sekarang, oleh karena itu para penganut legisme meyakini bahwa undang-undang telah lengkap dan jelas dalam mengatur segala persoalan di zamannya. Berkaca pada masa tersebut, maka menjadi benarlah pandangan positivisme Kelsen yang menyatakan bahwa tidak mungkin adanya kekosongan hukum, dikarenakan jika tata hukum tidak mewajibkan individu terhadap suatu perbuatan tertentu, maka ia bebas secara hukum, sepanjang negara tidak menetapkan apa-apa maka itu merupakan kebebasan pribadinya. ${ }^{12}$

Perkembangan sosial masyarakat yang mempengaruhi pula tuntutan akan perkembangan hukum yang dinamis menyebabkan setiap aturan-aturan hukum yang dibuat selalu satu langkah dibelakang realitas masyarakat. Hal ini dipengaruhi pula oleh pemanfaatan peraturan perundang-undangan yang ternyata mengandung masalah. Pertama, karena peraturan perundang-undangan yang tidak fleksible sehingga tidak mudah menyesuaikan dengan perkembangan masyarakat. Kedua, peraturan perundang-undangan tidak pernah lengkap untuk memenuhi segala peristiwa hukum sehingga menimbulkan kekosongan hukum (recht vacuum).13 Persoalan ini menyebabkan terjadinya kekacauan, ketidakadilan yang berujung pada bankruptcy of justice, yakni konsep yang mengacu pada kondisi di mana hukum tidak

${ }^{10}$ Caslav Pejovic, "Civil Law And Common Law: Two Different Paths Leading To The Same Goal", dalam http://www.victoria.ac.nz/law/research/publications/about-nzacl/publications/nzacl-yearbooks/yearbook-6,2000/Pejovic.pdf, Akses 20 Januari 2017.

${ }^{11}$ Dian Andriawan Dg Tawang dan Novina Sri Indiharti, Analisis Yuridis Terhadap Asas Ius Curia Novit dalam Hukum Acara Perdata, Laporan Penelitian Fakultas Hukum Universitas Trisakti Tahun 2001, hlm. 5. Dalam http://portal.kopertis3.or.id/bitstream/123456789/1874/1/Analisis Yuridis Terhadap Asas Ius Curia Novit dalam Hukum Acara Perdata.Pdf, Akses 22 Januari 2017.

12 Asep Dedi Suwasta, Tafsir Hukum Positif Indonesia, Ali Publishing, Bandung, 2011, hlm. 39.

${ }^{13}$ Ibid. 
dapat menyelesaikan perkara akibat ketiadan aturan hukum yang mengaturnya. ${ }^{14}$ Kenyataan demikian menyebabkan aliran legisme ditinggalkan dan asas ius curia novit menjadi sekedar sebagai fiksi hukum, dan sebagai kenyataan sudah mustahil untuk direalisasikan. ${ }^{15}$

Asas ius curia novit di Indonesia diturunkan dari Pasal 5 ayat (1) Undang-Undang No. 48 Tahun 2009 tentang Kekuasaan Kehakiman. Pasal 5 ayat (1) menyebut "Hakim dan hakim konstitusi wajib menggali, mengikuti, dan memahami nilai-nilai hukum dan rasa keadilan yang hidup dalam masyarakat". Asas ini sangat berkaitan dengan Asas rechtweigening atau dikenal dengan asas larangan menolak suatu perkara juga diturunkan dari Pasal 10 ayat (1) Undang-Undang Kekuasaan Kehakiman, yang menyebutkan "Pengadilan dilarang menolak untuk memeriksa, mengadili, dan memutus suatu perkara yang diajukan dengan dalih bahwa hukum tidak ada atau kurang jelas, melainkan wajib untuk memeriksa dan mengadilinya".

Menurut Sudikno Mertokusumo ${ }^{16}$, seorang hakim yang diajukan perkara kepadanya berkewajiban untuk memeriksa dan mengadili perkara tersebut hingga selesai meskipun apabila undang-undangnya tidak lengkap atau tidak ada, ia wajib menemukan hukumnya dengan jalan menafsirkan, menggali, mengikuti dan memahami nilai-nilai hukum yang hidup di dalam masyarakat. Penerapan Asas Ius Curia Novit menuntut kreatifitas hakim dalam menggunakan alat-alat untuk mewujudkannya yang berupa metode penemuan hukum.

Pada praktiknya tidak semua hakim tahu akan hukum, namun karena sistem hukum di Indonesia masih menganutnya maka dahulu untuk memaksa hakim menerapkan Asas Ius Curia Novit bahkan ditambahkan sanksi pidana Pasal 22 Algemene Bepalingen Van Wetgeving voor Indonesie (AB) atau Peraturan Umum mengenai Perundang-Undangan untuk Indonesia yang menyatakan, "Hakim yang menolak untuk mengadakan keputusan terhadap perkara, dengan dalih undang-undang tidak mengaturnya, terdapat kegelapan atau ketidaklengkapan dalam undang-undang dapat

${ }^{14}$ Asep Dedi Suwasta, Tafsir Hukum..., Op. Cit., hlm. 37.

15 Dian Andriawan Dg Tawang dan Novina Sri Indiharti, Analisis Yuridis Terbadap Asas Ius Curia Novit..., Op. Cit., hlm. 11.

${ }^{16}$ Sudikno Mertokusumo, Mengenal Hukum Suatu Pengantar, Liberty, Yogyakarta, 2008, hlm. 137. 
dituntut karena menolak mengadili perkara". ${ }^{17}$ Sanksi pidana ini meskipun sudah ditiadakan dan hanya menyisakan asas Rechtweigening (asas larangan menolak perkara) dalam Pasal 10 Undang-Undang No. 48 Tahun 2009 tentang Kekuasaan Kehakiman, namun ini menunjukkan tuntutan akan profesionalitas seorang hakim, sekaligus menjadi tuntutan bagi hakim untuk menerapkan asas ius curia novit. Seorang hakim harus memiliki pengetahuan dan wawasan yang dalam dan luas tentang hukum hingga hukum-hukum paling mutakhir sekalipun, oleh karena itu hakim tidak boleh berhenti belajar dan harus terus-menerus memperbaharui pengetahuan serta pemahamannya tentang hukum dan dinamikanya. ${ }^{18}$ Hakim tidak boleh begitu saja pasrah terhadap kondisi peraturan perundang-undangan yang tidak memadai karena masyarakat pencari keadilan (justiciabelen) selalu menaruh harapan yang tinggi dan kepercayaan bahwa perkara-perkara yang diajukan akan diperiksa dan diputus sesuai dengan hukum dan keadilan.

Hakim sebagai benteng terakhir keadilan wajib menerapkan asas ius curia novit dalam setiap putusannya. Putusan hakim haruslah mengandung penyelesaian sengketa sehingga merupakan akhir dari rangkaian proses pemeriksaan suatu perkara. Putusan hakim menurut Artidjo Alkostar merupakan bagian dari proses penegakan hukum yang bertujuan untuk mencapai kebenaran dan keadilan sehingga kualitas suatu putusan sangat berkorelasi dengan profesionalisme, kecerdasan moral, dan kepekaan nurani hakim. ${ }^{19}$

Pertimbangan hukum dalam putusan harus logis dan sesuai nalar hukum sehingga mewujudkan keadilan berdasarkan norma hukum dan akal sehat. Jika pertimbangan hukum dalam putusan tidak saling berhubungan dan bersesuaian sehingga putusan menjadi tidak cukup mempertimbangkan (Onvoldoende Gemotiveerd), maka akan terasa kejanggalan yang menimbulkan matinya akal sehat (the death of common sense) yang mana bahkan masyarakat yang paling awam pun akan merasakannya karena menyangkut nurani kemanusiaan. ${ }^{20}$

${ }^{17}$ Asep Dedi Suwasta, Tafsir Hukum..., Op. Cit., hlm. 6.

${ }_{18}$ Basuki Rekso Wibowo, "Pembaruan Hukum yang Berwajah Keadilan”, Varia Peradilan, Edisi No. 313 Ke-XXVII, Desember 2011, hlm. 11.

19 Artidjo Alkostar, "Dimensi Kebenaran dalam Putusan Pengadilan”, Varia Peradilan, Edisi No. 281 KeXXIV, April 2009, hlm. 36.

20 Artidjo Alkostar, Dimensi Kebenaran ..., Loc. Cit. 
Lebih lanjut menurut Artidjo Alkostar dalam upaya menemukan dan menerapkan keadilan dan kebenaran, putusan pengadilan harus sesuai dengan tujuan asasi yaitu tujuan putusan pengadilan yang sejatinya ada lima hal. Pertama, harus merupakan solusi autoritatif, artinya putusan haruslah memberikan jalan keluar dari masalah hukum yang dihadapi oleh para pihak. Kedua, karena keadilan yang tertunda adalah juga merupakan ketidakadilan (justice delayed is justice denied) maka putusan hakim harus mengandung efisiensi, yaitu cepat, sederhana dan biaya ringan. Ketiga, putusan hakim haruslah sesuai dengan tujuan undangundang yang dijadikan dasar putusan tersebut. Keempat, putusan yang dibentuk harus mengandung aspek stabilitas yaitu ketertiban sosial dan ketentraman masyarakat. Kelima, adanya pemberian kesempatan yang sama bagi para pihak yang berperkara.

Penerapan Asas Ius Curia Novit dalam putusan hakim juga menekankan kebebasan hakim dalam memutus. Hakim harus bebas dari pengaruh kekuasaan lain diluar kekuasaan pegadilan, namun juga harus bebas dari pengaruh kepentingannya sendiri. Kebebasan bagi hakim dalam memutus merupakan kunci bagi putusan-putusan yang sehat. Tanpa kebebasan hakim maka tidak terbuka kemungkinan bagi putusan yang bernafaskan keadilan, kemanfaatan dan kepastian hukum.

Kebebasan hakim pada hakikatnya juga merupakan kebebasan bagi hakim dalam proses pemeriksaan perkara. Hakim bebas memberikan suatu putusan berdasarkan hukum dan keyakinannya. Hakim tidak boleh hanya menjadi corong dan mulut undang-undang meskipun memang selalu legalistik. Dengan kata lain, seperti yang dikatakan oleh Bagir Manan putusan hakim tidak boleh sekedar memenuhi formalitas hukum atau sekedar memelihara ketertiban, namun juga harus berfungsi dalam mendorong perbaikan dalam masyarakat dan membangun harmonisasi sosial dalam pergaulan. ${ }^{21}$

Hubungan kebebasan hakim dan Asas Ius Curia Novit sangat kentara terlihat ketika hakim dihadapkan pada kekosongan hukum atau ketidakjelasan undang-

${ }^{21}$ H.A. Mukhsin Asyrof, Asas-Asas Penemuan Hukum..., Op. Cit., hlm. 85. 
undang, karena dengan adanya kebebasan hakim dalam memberikan putusan telah sejalan dengan perintah undang-undang yang mewajibkan hakim sebagai penegak hukum dan keadilan untuk menggali, mengikuti dan memahami nilainilai hukum yang hidup di masyarakat ${ }^{22}$.

Demi mewujudkan keadilan bagi para pencari keadilan yang memohon putusan kepadanya, seorang hakim wajib menggali hukum tidak tertulis andaikata tidak diketemukan dasarnya dalam hukum tertulis, bahkan jika ketentuan undangundang yang ada justru dirasakan bertentangan dengan kepentingan umum, kepatutan, peradaban dan kemanusiaan atau nilai-nilai yang hidup di masyarakat maka menurut Yahya Harahap hakim bebas dan berwenang melakukan tindakan contra legem, yakni mengambil putusan yang bertentangan dengan pasal undangundang yang bersangkutan. ${ }^{23}$

Besarnya kewenangan hakim dalam memberikan putusan tidak serta merta membebaskan hakim untuk bertindak sewenang-wenang oleh karena itu harus diciptakan batasan-batasan tanpa mengorbankan prinsip kebebasan sebagai hakikat kekuasaan kehakiman. Mengenai hal ini Alfred M. Scott dalam bukunya Supreme Court v Constitusion, pernah menyatakan: ${ }^{24}$

"hakim yang menyimpang dan menolak mengikuti hukum yang ada, dan melakukan improvisasi serta menetapkan hukum menurut kemauannya sendiri adalah perampas kekuasaan yang secara hukum bukan kekuasaannya, dia adalah seorang tirani yang menjalankan kediktatoran yudisial, dan sadar atau tidak (hakim tersebut) mengubah tatanan bernegara dari pemerintahan berdasarkan hukum menjadi pemerintahan oleh orang perorangan dan pemerintahan oleh orang perorangan sama dengan kediktatoran."

Untuk menghindari kebebasan hakim yang tanpa kendali sehingga dikhawatirkan menjadi sewenang-wenang maka menurut Bagir Manan ada lima batasan yang tidak boleh dilampaui hakim yaitu: hakim hanya memutus berdasarkan hukum; hakim dilarang memutus diluar apa yang dituntut atau dimohonkan (ultra petita); hakim memutus untuk memberikan keadilan dan tidak

22 Pontang Moerad, Pembentukan Hukum melalui Putusan Pengadilan dalam Perkara Pidana, Alumni, Bandung, 2005, hlm. 102.

${ }^{23}$ H.A. Mukhsin Asyrof, Asas-Asas Penemuan Hukum... Loc. Cit.

${ }_{24}$ Alfred M. Scott, Supreme Court V Constitusion, sebagaimana dikutip ulang oleh, Bagir Manan, "Judicial Precedent dan Stare Decisis (Sebagai Pengenalan)", Varia Peradilan, Edisi No. 347 Ke-XXX, Oktober 2014, hlm. 17. 
untuk kepentingan lain di luar itu; hakim wajib memeriksa apakah suatu objek perkara atau sengketa yang diajukan masih berada di dalam wewenang pengadilan (justiability) atau di luar wewenang pengadilan (non justiability); dan hakim harus terbebas dari segala bentuk permainan politik dalam memutus perkara dan tidak mencampuri kewenangan legislatif sebagai pembentuk undangundang serta eksekutif sebagai penentu kebijakan pemerintah.

Pada konteks penemuan hukum, menurut Bagir Manan, ${ }^{25}$ ada empat faktor yang mendorong hakim berkewajiban untuk melakukan penemuan hukum. Pertama, hampir semua peristiwa hukum konkrit tidak sepenuhnya secara tepat diatur di dalam undang-undang. Kedua, karena ketentuan peraturan perundangundangan yang tidak jelas atau justru bertetangan dengan peraturan perundangundangan lain yang memerlukan pilihan agar dapat diterapkan secara benar, tepat dan adil. Ketiga, akibat dinamika masyarakat, terjadi berbagai macam peristiwa hukum baru yang tidak terlukis dalam undang-undang atau peraturan perundangundangan. Keempat, asas larangan hakim untuk menolak perkara dan juga asas ius curia novit yang mewajibkan hakim untuk menemukan hukumnya.

Menurut Bambang Sutiyoso, bahwa dasar keharusan hakim dalam melakukan penemuan hukum adalah adanya Asas Ius Curia Novit. ${ }^{26}$ Menurutnya apabila hakim dalam memeriksa perkara yang diajukan kepadanya menghadapi perkara yang tidak ada aturan hukumnya atau ada aturan hukumnya, namun aturan hukum tersebut tidak jelas maka hakim wajib mencari hukum tersebut dari nilai-nilai hukum dan rasa keadilan yang hidup dan berkembang di masyarakat. Menurut Wiarda, ada tiga sistem penemuan hukum yaitu penemuan hukum heteronom, penemuan hukum otonom dan penemuan hukum campuran.27 Penemuan hukum heteronom masih mengacu pada pandangan klasik bahwa semua hukum terdapat secara lengkap dan sistematis dalam undang-undang dan tugas hakim adalah mengadili sesuai atau menurut bunyi undang-undang (bouche

${ }^{25}$ Bagir Manan, “Hakim Sebagai Pembaharu Hukum”, V aria Peradilan, Edisi No. 254 Ke-XXII, Januari 2007, hlm. 10 .

${ }^{26}$ Bambang Sutiyoso, Metode Penemuan Hukum Upaya Mewnjudkan Hukum yang Pasti dan Berkeadilan, UII Press, Yogyakarta, 2006, hlm. 31.

27 Wiarda, Drie Typen Van Rechtvinding, dalam Ibid 
de la loi), sementara penemuan hukum otonom adalah penemuan hukum yang bukan semata-mata hanya penerapan peraturan-peraturan hukum terhadap peristiwa konkretnya tetapi sekaligus juga merupakan penciptaan dan pembentukan hukum. Hakim yang menganut penemuan hukum otonom dapat memeriksa dan memutus menurut apresiasinya sendiri berdasarkan keyakinan dan kesadaran hukumnya.

Pada perkembangannya kedua sistem penemuan hukum telah saling mempengaruhi sehingga tidak ada penemuan hukum yang benar-benar murni otonom atau penemuan hukum yang murni heteronom. ${ }^{28}$ Di Indonesia menurut Sudikno Mertokusumo, mengenal baik penemuan hukum heteronom maupun otonom. Hakim terikat pada undang-undang namun hakim seringkali pula harus menjelaskan atau melengkapi undang-undang menurut pandangannya sendiri. Sumber utama penemuan hukum di Indonesia adalah peraturan perundangundangan, apabila kemudian tidak diketemukan barulah mencari secara berurutan pada hukum kebiasaan, yurisprudensi, perjanjian internasional dan doktrin. ${ }^{29}$

Asas ius curia novit sebagaimana diuraikan di atas, ini penting diperhatikan ketika dihadapkan dengan Putusan Mahkamah Konstitusi No. 21/PUU-XII/2014, dengan konsekuensi berupa penambahan objek pemeriksaan praperadilan yang salah satunya adalah pengujian keabsahan penetapan tersangka, namun tidak diikuti dengan aturan yang jelas khususnya mengenai hal-hal yang dapat membatalkan suatu penetapan tersangka. Perma No. 4 Tahun 2016 sendiri substansi utamanya adalah pedoman bagi hakim tentang larangan peninjauan kembali perkara praperadilan tidak secara khusus dapat menjadi pedoman dalam pengujian penetapan tersangka.

Dapat disimpulkan permasalahan hukum yang terjadi sesungguhnya, bukanlah kekosongan undang-undang (wet vacuum) atau ketidaklengkapan undang-undang karena pengujian penetapan tersangka sebagai salah satu kewenangan praperadilan telah diputus dalam amar Putusan Mahkamah Konstitusi yang final dan mengikat sehingga kekuatan berlakunya setara dengan

\footnotetext{
28 Ibid., hlm. 44.

29 Sudikno Mertokusumo, Penemuan Hukum Sebuah Pengantar, Cetakan Kelima, Universitas Atmajaya, Yogyakarta, 2010, hlm. 63.
} 
undang-undang. Ketersedian aturan pengujian penetapan tersangka sebagai salah satu kewenangan praperadilan telah termuat dalam amar Putusan Mahkamah Konstitusi, oleh karena itu penemuan hukum dengan metode argumentasi dan konstruksi hukum tidak tepat untuk digunakan. Metode penafsiran hukum atau interpretasi lebih tepat digunakan oleh hakim ketika melakukan penafsiran Putusan Mahkamah Konstitusi agar dapat diterapkan dalam pemeriksaan permohonan praperadilan terkait penetapan tersangka.

Kekurangjelasan aturan mengenai hal-hal yang dapat membatalkan suatu penetapan tersangka pada hakikatnya adalah kekurang jelasan pada Hukum Acara Pidana karena secara umum praperadilan diatur didalam KUHAP yang termasuk lingkup hukum pidana formil. Sebagaimana karakteristik khusus yang terdapat dalam Hukum Acara Pidana dan tidak terdapat dalam bidang disiplin hukum lainnya seperti Hukum Perdata maka tidak seluruh metode interpretasi yang tersedia cocok dan dapat digunakan dalam penafsiran hukum pengujian penetapan tersangka.

Interpretasi terhadap Hukum Acara Pidana hendaknya juga memperhatikan asas yang berlaku dalam Hukum Acara Pidana khususnya apabila asas tersebut dapat mempengaruhi dalam penafsirannya. Asas tersebut adalah asas lex scripta dan lex stricta yang diturunkan dari asas legalitas Hukum Acara Pidana dalam Pasal 3 KUHAP. Menurut Eddy O. S. Hiariej, asas lex scripta berarti bahwa Hukum Acara Pidana yang mengatur proses beracara dengan segala kewenangan yang ada harus tertulis, sementara asas lex stricta menyatakan bahwa aturan dalam Hukum Acara Pidana harus ditafsirkan secara ketat. ${ }^{30}$ Hukum Acara Pidana harus ditafsirkan menurut apa yang tertulis karena karakter dari Hukum Acara Pidana pada hakikatnya adalah mengekang hak asasi manusia. Penafsiran terhadap Hukum Acara Pidana harus memperhatikan kewenangan negara untuk mengambil segala tindakan dalam rangka penegakan hukum, dan di sisi yang lain juga harus memperhatikan pembatasan kewenangan tersebut oleh undang-undang secara ketat.

30 Eddy O.S. Hiariej, Modul Pengantar Hukum Acara Pidana, dalam http://repository.ut.ac.id/4124/1 /HKUM4406-M1.pdf, Akses 3 Februari 2017. 
Dari empat puluh dua putusan yang diteliti, secara umum permohonan praperadilan pengujian keabsahan penetapan tersangka selalu diikutsertakan dengan permohonan pengujian sah tidaknya penangkapan, penahanan, penggeledahan dan penyitaan. Hal ini karena para tersangka umumnya menyadari bahwa batalnya suatu penetapan terhadap dirinya sebagai tersangka akan membuat penetapan serta tindakan penyidik lainnya berdasarkan penetapan tersangka tersebut menjadi batal.

Penetapan tersangka selain menjadi pintu masuk bagi penyidik untuk melakukan upaya paksa lainnya, juga merupakan kesempatan bagi tersangka untuk membatalkan seluruh upaya paksa yang dideritanya melalui permohonan praperadilan. Hal ini merupakan kesempatan bagi tersangka dan penasihat hukumnnya untuk mengajukan permohonan pengujian penetapan tersangka disertai dalil-dalil yang membuktikan bahwa tindakan penyidik dalam menetapkan tersangka telah bertentangan dengan ketentuan hukum.

Praktiknya berdasarkan putusan-putusan yang diteliti, putusan hakim juga dipengaruhi oleh dalil-dalil pemohon. Hakim bertindak pasif setelah mendengarkan dalil pemohon dan sangkalan dari penyidik, sehingga hanya persoalan yang didalilkan oleh pemohon sajalah yang akan diperiksa oleh hakim tunggal praperadilan. Hal lain yang juga sangat berpengaruh dalam pertimbangan putusan praperadilan adalah penafsiran hukum oleh hakim itu sendiri. Hakim yang sama cenderung memberikan pertimbangan yang sama menyangkut hal-hal yang dapat membatalkan suatu penetapan tersangka, sementara hakim yang berbeda cenderung akan memberikan pertimbangan yang berbeda meskipun terhadap kasus yang hampir sama.

Disparitas putusan hakim khususnya pada penafsiran hukum putusan praperadilan yang menguji sah tidaknya penetapan tersangka tidak bisa terhindarkan lagi. Secara garis besar disparitas yang terjadi dapat dijelaskan menjadi dua yaitu disparitas putusan secara umum dan disparitas putusan secara khusus. Secara umum berarti disparitas terjadi meskipun tidak mempengaruhi hasil akhir putusan praperadilan dan tidak hanya spesifik terjadi pada perkara praperadilan pengujian sah tidaknya penetapan tersangka yaitu mengenai hukum acara yang digunakan dalam praperadilan. 
Tidak jelasnya hukum acara yang digunakan dalam praperadilan penetapan tersangka menyebabkan disparitas dalam putusan hakim khususnya antara Putusan No. 01/Para.Pid/2016/PN.Psb, Pengadilan Negeri Pasaman Barat; dan Putusan No. 4/Pid.Pra/2016/PN YYK, Pengadilan Negeri Yogyakarta. Menurut Putusan No. 01/Para.Pid/2016/PN.Psb hukum acara yang digunakan dalam praperadilan adalah Hukum Acara Pidana sehingga permohonan diajukan di tempat kejadian perkara (locus delicti), sementara sebaliknya Putusan No. 4/Pid.Pra/2016/PN YYK menyatakan bahwa hukum acara yang digunakan dalam praperadilan adalah Hukum Acara Perdata sehingga menganut azas domisili tergugat (actor sequitor forum rei) yaitu gugatan didaftarkan di mana alamat domisili termohon, sesuai Pasal 118 ayat (1) HIR/142 ayat (1) Rbg bukan di tempat kejadian perkara atau locus delicti.

Bentuk disparitas lainnya yang terjadi dalam pertimbangan putusan hakim praperadilan yang memeriksa permohonan pengujian penetapan tersangka adalah disparitas khusus yaitu disparitas putusan hakim yang terjadi khusus pada praperadilan pengujian penetapan tersangka dan sifatnya mempengaruhi hasil akhir putusan hakim. Disparitas khusus ini dapat dikelompokkan menjadi dua yaitu pertama, putusan-putusan hakim yang menafsirkan sah tidaknya penetapan tersangka berdasarkan Putusan Mahkamah Konstitusi No. 21/PUU-XII/2014 dan KUHAP baik secara ketat, maupun secara longgar, dan kedua adalah putusan hakim yang menggunakan penafsiran hukum dalam pengujian penetapan tersangka namun diluar yang ditentukan oleh Putusan Mahkamah Konstitusi No. 21/PUU-XII/2014.

\section{Penafsiran Hukum dalam Putusan Hakim berdasarkan Putusan Mahkamah Konstitusi No. 21/PUU-XII/2014 dan KUHAP. \\ Mayoritas hakim dalam putusan yang diteliti berpendapat sah tidaknya} penetapan seseorang sebagai tersangka mengacu pada definisi penyidikan pada Pasal 1 butir ke-2 KUHAP yang menyatakan "penyidikan adalah serangkaian tindakan penyidik dalam hal menurut cara yang diatur dalam undang-undang ini untuk mencari serta mengumpulkan bukti yang dengan bukti itu membuat terang tentang tindak pidana yang terjadi dan guna menemukan tersangkanya", serta definisi tersangka pada pasal 1 butir ke-14 KUHAP yang menyatakan "tersangka adalah seorang yang karena 
perbuatannya atau keadaannya, berdasarkan bukti permulaan patut diduga sebagai pelaku tindak pidana".

Berdasarkan definisi kedua pasal tersebut kemudian diperjelas kembali oleh Putusan Mahkamah Konstitusi No. 21/PUU-XII/2014 yang dalam pertimbangannya menyatakan:

"frasa "bukti permulaan", "bukti permulaan yang cukup", dan "bukti yang cukup" sebagaimana ditentukan dalam Pasal 1 angka 14, Pasal 17, dan Pasal 21 ayat (1) KUHAP harus ditafsirkan sekurang-kurangnya dua alat bukti yang termuat dalam Pasal 184 KUHAP dan disertai dengan pemeriksaan calon tersangkanya, kecuali terhadap tindak pidana yang penetapan tersangkanya dimungkinkan dilakukan tanpa kehadirannya (in absentia). Artinya, terhadap tindak pidana yang penetapan tersangkanya dimungkinkan dilakukan tanpa kehadirannya tersebut, tidak diperlukan pemeriksaan calon tersangka."

Dengan demikian, berdasarkan Pasal 1 angka 2 dan angka 14 KUHAP serta pertimbangan Putusan Mahkamah Konstitusi No. 21/PUU-XII/2014 tersebut, mayoritas putusan hakim menyimpulkan ada tiga norma yang wajib terkandung dalam suatu penetapan tersangka yaitu: pertama, norma kewenangan, bahwa penegak hukum yang melakukan tindakan penyelidikan, penyidikan hingga penetapan seseorang sebagai tersangka haruslah berwenang berdasarkan ketentuan peraturan perundang-undangan yang berlaku. Kedua, prosedural, artinya sebelum melakukan penetapan tersangka harus dipenuhi dahulu tindakantindakan yang diperlukan seperti melakukan proses penyelidikan, penyidikan dan pengumpulan dua alat bukti sesuai Pasal 184 KUHAP disertai pemeriksaan calon tersangkanya. Prosedural juga bermakna setiap surat yang dikeluarkan oleh aparat penegak hukum dalam rangka penyidikan baik itu surat perintah penyidikan, surat panggilan pemeriksaan saksi hingga berita acara pemeriksaan haruslah bersifat resmi dan tidak bertentangan dengan Hukum Acara Pidana. Ketiga, formal, artinya syarat terpenuhinya dua alat bukti sesuai Pasal 184 KUHAP dan disertai pemeriksaan calon tersangkanya harus benar-benar dilakukan pada proses penyidikan, bukan dalam proses penyelidikan atau justru setelah penetapan tersangka karena penetapan tersangka dasarnya harus terpenuhi dua alat bukti yang cukup maka bukti-bukti harus ditemukan sebelum tersangka ditetapkan. Bukti-bukti sebagai dasar penetapan tersangka haruslah benar-benar ada sesuai Pasal 184 KUHAP sehingga dapat ditunjukkan aslinya pada saat sidang praperadilan. 
Penerapan ketiga norma ini dalam praperadilan penetapan tersangka masih terdapat disparitas, yakni mengenai pemaknaan masing-masing norma tersebut dalam praktek. Sebagai contoh dalam norma kewenangan terjadi disparitas antara Putusan 36/Pid.Prap/2015/PN.JKT.Sel dan Putusan 119/Pid.Prap/2015/PN.Jkt-Sel, putusan yang pertama menyatakan bahwa Penyelidik dan Penyidik Komisi Pemberantasan Korupsi yang tidak berasal dari Instansi Kepolisian tidak berwenang melakukan tindakan penyelidikan dan penyidikan sehingga penyidikan yang telah dilakukan menjadi tidak sah, namun ternyata penafsiran hukum ini tidak diikuti oleh putusan yang terakhir yang menyatakan bahwa hakim tidak wajib mengikuti putusan terdahulu dan Putusan No. 36/Pid.Prap/2015/PN.JKT.Sel bukanlah penjelasan resmi Undang-Undang 30 Tahun 2002 tentang Komisi Pemberantasan Korupsi, sehingga Komisi Pemberantasan Korupsi (KPK) berhak mengangkat penyelidik dan penyidik sendiri di luar penyelidik dan penyidik dari Instansi Kepolisian yang ditugaskan pada KPK.

Disparitas juga terjadi pada pemaknaan norma formal yaitu mengenai tersedianya dua alat bukti, namun tanpa disertai pemeriksaan terhadap calon tersangka dan bahkan sering diganti pengertiannya dengan "telah pernah diperiksa sebagai tersangka", yang sangat berbeda dan bertentangan dengan Putusan Mahkamah Konstitusi No. 21/PUU-XII/2014. Contohnya yaitu antara Putusan No. 1/Pid.Prap/2016/PN Mjn dan Putusan No. 3/Pid.Pra/2015/PN Kla.

Pada norma prosedural terdapat pula disparitas antara putusan hakim yang mempertimbangkan telah dilakukannya penyelidikan dan penyidikan secara formal dengan putusan-putusan yang menelitinya mengenai tanggal-tanggal dilakukannya penyelidikan dan penyidikan. Hal ini karena pemeriksaan saksisaksi dan pengumpulan bukti-bukti harus dilakukan saat penyidikan bukan sebelum maupun setelah penyidikan atau setelah tersangka ditetapkan, di samping itu tindakan penetapan tersangka harus dilakukan setelah melalui proses penyidikan, tidak sebelum atau bertepatan dengan Surat Perintah Penyidikan sebagai tanda dimulainya penyidikan. Sebagai contoh, Putusan No. 5/Pid.Prap/2015/PN.Kfm, dan Putusan No. 36/Pid.Prap/2015/PN.JKT.Sel. 
Masih terdapatnya putusan-putusan yang hanya mempertimbangkan telah dilakukannya penyelidikan dan penyidikan tentunya berbanding terbalik dengan putusan yang menelitinya lebih detail mengenai kapan penyelidikan dan penyidikan dilakukan serta kapan bukti-bukti dikumpulkan. Adanya disparitas penafsiran hukum hakim dalam pertimbangan putusan praperadilan mengenai pemaknaan terhadap ketiga norma yakni, norma kewenangan, prosedural dan formal secara ketat dengan putusan hakim lainnya yang hanya memaknainya secara longgar atau hanya mengambil salah satu norma saja sebagai dasar pertimbangannya tentunya menyebabkan hasil akhir putusan yang berbeda.

\section{Penafsiran Hukum dalam Putusan Hakim Di Luar yang Ditentukan oleh Putusan Mahkamah Konstitusi No. 21/PUU-XII/2014}

Di samping putusan hakim yang memutuskan berdasarkan penafsiran hukum terhadap Putusan Mahkamah Konstitusi No. 21/PUU-XII/2014 dan KUHAP juga terdapat penafsiran hukum lain oleh hakim dalam putusan praperadilan pengujian penetapan tersangka di luar yang ditentukan oleh Putusan Mahkamah Konstitusi No. 21/PUU-XII/2014 bentuk penafsiran hukum tersebut diantaranya: pertama, penolakan Putusan Mahkamah Konstitusi No. 21/PII-XII/2014. Dari 42 putusan yang diteliti hanya satu putusan yang menolak perluasan obyek kewenangan praperadilan yaitu pemeriksaan terhadap sah tidaknya penetapan tersangka putusan tersebut adalah Putusan No. 1/Pid.Prap/2015/PN.Bta, Pengadilan Negeri Baturaja. Menurut pertimbangan putusan ini KUHAP telah mengatur secara limitatif tindakan hukum apa saja yang dapat diuji pada praperadilan dan tidak termasuk penetapan tersangka. Putusan ini sekaligus menolak amar Putusan Mahkamah Konstitusi No. 21/PIIXII/2014 untuk menguji permohonan pengujian penetapan tersangka di ranah praperadilan.

Kedua, asas retroaktif Putusan Mahkamah Konstitusi No. 21/PII-XII/2014. Terdapat disparitas dalam putusan praperadilan yang menerapkan Asas Retroaktif Putusan Mahkamah Konstitusi No. 21/PII-XII/2014 sebagai dasar penolakan pengujian penetapan tersangka. Putusan tersebut adalah Putusan No. 1/Pid.Prap/ 2015/PN.Kfm, dan Putusan No. 3/Pid.Prap/2015/PN.Kfm yang inti pertimbangan putusannya sama yaitu penetapan tersangka telah dilakukan penyidik pada tanggal 21 Mei 2014 sementara Putusan Mahkamah Konstitusi No. 21/PII-XII/2014 baru 
diputus final dan mengikat pada 28 April 2015 sehingga tidak dapat diberlakukan surut dan permohonan praperadilan pengujian penetapan tersangka ditolak.

Berbeda dengan pertimbangan kedua putusan tersebut, tiga putusan berikutnya dari pengadilan yang sama yaitu Pengadilan Negeri Kefamenanu justru memutuskan sebaliknya. Putusan No. 2/Pid.Prap/2015/PN.Kfm, Putusan No. 4/Pid.Prap/2015/ PN.Kfm dan Putusan No. 5/Pid.Prap/2015/PN.Kfm justru mengabulkan permohonan pemeriksaan pengujian penetapan tersangka berdasarkan amar Putusan Mahkamah Konstitusi No. 21/PII-XII/2014 meskipun tanggal penetapan tersangka pada masing-masing putusan tersebut satu tahun sebelum berlakunya Putusan Mahkamah Konstitusi No. 21/PII-XII/ 2014 atau sebelum 28 April 2015.

Ketiga, Perkara telah nebis in idem. Hanya satu putusan yang mengabulkan permohonan pemohon mengenai tidak sahnya penetapan tersangka karena perkara telah nebis in idem yakni Putusan No. 11/PRAPER/2016/PN.SBY karena sebelumnya pemohon telah diputus berdasarkan putusan inkracht dan telah mempertanggungjawabkan perbuatannya.

Menurut Hakim Wisnu Kristiyanto, memutuskan bahwa suatu perkara telah nebis in idem pada saat pemeriksaan praperadilan adalah sangat tidak tepat karena berarti telah memeriksa materi pokok perkara sehingga lebih tepat putusan nebis in idem di putus saat pokok perkaranya disidangkan.

Keempat, perkara telah daluwarsa. Putusan No. 19/Pid.Prap/2016/PN.Jkt.Sel mengabulkan permohonan pemohon bahwa penetapan tersangka tidak sah karena bukti surat yang digunakan untuk menetapkan pemohon sebagai tersangka yang diduga menggunakan surat palsu ternyata kewenangan menuntut pidananya hapus karena daluwarsa berdasarkan Pasal 78 ayat (1) Ke 3 KUHP jo. Pasal 79 Ke 1 KUHP. Hakim Heriyenti ${ }^{31}$ tidak sependapat jika daluwarsa diputuskan pada saat pemeriksaan praperadilan karena telah ikut memeriksa kualitas alat bukti surat yang digunakan sebagai dua alat bukti untuk menetapkan seseorang sebagai tersangka.

31 Wawancara dengan Hakim Heriyenti, SH. di Pengadilan Negeri Yogyakarta yang salah satu putusannya ikut diteliti dalam penelitian ini. 
Kelima, Perma No. 1 Tahun 1956. Peraturan Mahkamah Agung No. 1 Tahun 1956 Pasal 1, menyatakan apabila pemeriksaan perkara pidana harus diputuskan hal adanya suatu hal perdata perdata atas suatu barang atau tentang suatu hubungan hukum antara dua pihak tertentu, maka pemeriksaan perkara pidana dapat dipertangguhkan untuk menunggu suatu putusan pengadilan dalam pemeriksaan perkara perdata tentang adanya atau tidak adanya hak perdata itu. Putusan No. 11/Pra.Per/2015/PN.Jkt.Ut memutuskan bahwa penetapan pemohon sebagai tersangka prematur karena ini berkaitan dengan sengketa kepemilikan tanah antara pemohon dengan pelapor, yang mana tanah tersebut belum jelas siapa yang memiliki berdasarkan putusan pengadilan.

Keenam, mempertimbangkan unsur pokok pasal. Hanya satu putusan yang ikut mempertimbangkan penerapan suatu pasal dalam penetapan seorang tersangka yaitu Putusan No. 1/Pid.Prap/2016/PN.Bms. Putusan ini menyatakan surat perintah penyidikan dan surat penetapan tersangka tidak sah, tidak mempunyai kekuatan hukum mengikat karena melanggar Undang-Undang No. 23 Tahun 2014 tentang Pemerintahan Daerah dan Undang-Undang No. 30 Tahun 2014 tentang Administrasi Pemerintahan sehingga bila terbukti ada penyimpangan administratif maka diserahkan kepada APIP (Aparat Pengawas Internal Pemerintah) dan bila terbukti ada penyimpangan pidana maka proses diserahkan kepada aparat penegak hukum sebagaimana Pasal 385 ayat (4) dan ayat (5) Undang-Undang No. 30 Tahun 2014 tentang Administrasi Pemerintahan. Menurut Putusan ini Hukum Pidana dipandang sebagai Ultimum Remidium dijadikan upaya terakhir dalam penegakan hukum apabila suatu tindak pidana dapat diselesaikan melalui jalur lain hendaklah jalan tersebut terlebih dahulu dilalui yakni penyelesaian secara kekeluargaan, negosiasi, mediasi perdata, ataupun Hukum Administrasi. Putusan No. 1/Pid.Prap/2016/PN.Bms ini merupakan putusan yang paling bertentangan dengan putusan-putusan lainnya, di saat mayoritas putusan menolak permohonan pemeriksaan terhadap materi pokok perkara namun putusan ini justru memasuki penafsiran hukum dalam penerapan pasal yang diterapkan terhadap tersangka.

Di samping disparitas, penafsiran hukum putusan hakim praperadilan ternyata juga menunjukkan keseragaman apabila menyangkut hal-hal yang bukan 
obyek praperadilan. Pada umumnya permohonan untuk turut menguji kondisikondisi tersebut telah ditolak dalam mayoritas putusan hakim karena dipandang bukan merupakan obyek kewenangan yang dapat diperiksa dalam ranah praperadilan, dengan kata lain persoalan tersebut tidak mempengaruhi keabsahan suatu penetapan tersangka yang telah dilakukan. Beberapa persoalan yang sering ditolak untuk ikut diperiksa dalam praperadilan penetapan tersangka yaitu: Pertama, materi pokok perkara yaitu menyangkut unsur-unsur pasal pidana yang dituduhkan kepada tersangka, atau menyangkut pembuktian materiil terhadap suatu perkara pidana tersebut. Kedua, lamanya status tersangka, terutama dari putusan yang diteliti bervariasi antara 1 hingga 4 tahun namun tidak satupun dari putusan-putusan tersebut yang mempertimbangkan bahwa pelanggaran hak tersangka untuk segera diperiksa dan perkaranya dimajukan ke pengadilan dapat membatalkan suatu penetapan tersangka. Ketiga, kesalahan surat menyurat yang tidak substansial mengganggu jalannya pemeriksaan tersangka.

Masih terjadinya disparitas putusan hakim dalam putusan praperadilan yang memeriksa pengujian penetapan tersangka menandakan perlunya pedoman lebih lanjut bagi hakim guna dijadikan pegangan para hakim dalam memeriksa perkara praperadilan pengujian penetapan tersangka. Menurut Hakim Wisnu Kristiyanto, perkembangan hukum dalam gugatan praperadilan telah terjadi di mana pelanggaran HAM dijadikan pintu masuk bagi para tersangka dalam menggugat suatu penetapan tersangka sehingga tidak terbatas pada dua alat bukti dan pemeriksaan calon tersangkanya, oleh karena itu butuh pedoman lagi bagi hakim agar memiliki parameter yang pasti dalam pemeriksaan praperadilan penetapan tersangka. Lebih lanjut menurutnya, masih banyak hal-hal yang perlu pengaturan lebih lanjut seperti hukum acara bagi pemeriksaan praperadilan, kejelasan mengenai syarat-syarat penyidik dan penyidik pegawai negeri sipil yang berhak melakukan penyidikan, serta batas waktu bagi seseorang yang ditetapkan sebagai tersangka agar segera dimajukan ke persidangan.

Menurut Hakim Heriyenti, pengaturan mengenai praperadilan penetapan tersangka yang masih terpecah seperti saat ini di KUHAP dan di Putusan Mahkamah Konstitusi No. 21/PUU-XII/2014 menyulitkan hakim dalam mencari 
aturannya, sehingga perlu adanya aturan baru yang lebih lengkap disatukan di dalam Hukum Acara Pidana yang akan datang.

Penulis sendiri sependapat dengan pendapat tersebut berdasarkan penelitian dari 42 putusan hakim ternyata masih terjadi disparitas dalam putusan hakim yang disebabkan kekurangjelasan aturan menyangkut praperadilan penetapan tersangka. Para hakim telah mencoba mengisi aturan yang kurang jelas tersebut dengan cara melakukan penafsiran hukum terhadap KUHAP dan Putusan Mahkamah Konstitusi No. 21/PUU-XII/2014. Akan tetapi, sebagaimana pendapat Tjandra Sridjaja Pradjonggo, bukan tidak mungkin akibat perbedaan pengetahuan, kemampuan atau pengalaman hakim mengakibatkan timbulnya pertimbangan-pertimbangan hukum dan akhirnya melahirkan putusan hakim yang berbeda dalam kasus yang hampir sama karena interpretasi yang digunakan hakim berbeda. ${ }^{32}$

Menurut penulis setidak-tidaknya perlu pengaturan kembali terkait praperadilan penetapan tersangka pada Hukum Acara Pidana yang akan datang terutama mengenai hukum acara yang jelas yang digunakan dalam pemeriksaan praperadilan, serta parameter yang pasti mengenai suatu penetapan tersangka yang dilakukan oleh penyidik yang sah. Hal-hal lain yang belum diatur dan merupakan pelanggaran atas hak-hak tersangka juga perlu dirumuskan apakah pelanggaran tersebut dapat berdampak pada batalnya suatu penetapan tersangka seperti penggantungan status tersangka yang terlalu lama hingga bertahun-tahun atau terhadap tersangka yang tidak memperoleh bantuan hukum saat dilakukan pemeriksaan.

\section{Penutup}

Pada kenyataannya tidak semua hakim tahu akan hukumnya, sebagaimana hasil penelitian dari 42 putusan praperadilan yang diteliti, terdapat satu putusan yang tidak mengakui Putusan Mahkamah Konstitusi No. 21/PUU-XII/2014, selebihnya masih terjadi disparitas putusan hakim praperadilan yang menguji keabsahan suatu penetapan tersangka meskipun secara keseluruhan penafsiran yang dilakukan hakim bersumber pada KUHAP dan Putusan Mahkamah

32 Tjandra Sridjaja Pradjonggo, Sifat Melawan Hukum dalam Tindak Pidana Korupsi, Cetakan Pertama, Jakarta Lawyer Club, Surabaya, 2010, hlm. 42. 
Konstitusi No. 21/PUU-XII/2014. Hingga kini masih belum terbentuk adanya kesamaan pendapat hukum dikalangan para hakim mengenai suatu penetapan tersangka yang dipandang sah serta penafsiran hukum terkait hal-hal yang harus dipenuhi dalam suatu penetapan tersangka. Oleh karena itu, guna mewujudkan terciptanya kesamaan pendapat hukum (unified legal opinion) dan keseragaman kerangka kerja hukum (unified legal frame work) secara objektif, di masa yang akan datang perlu pengaturan kembali terkait praperadilan penetapan tersangka dengan ditambahkan pada Hukum Acara Pidana, terutama mengenai hukum acara yang jelas digunakan dalam pemeriksaan praperadilan, serta parameter yang pasti mengenai suatu penetapan tersangka oleh penyidik yang dipandang sah. Halhal lain yang belum diatur dan merupakan pelanggaran atas hak-hak tersangka juga perlu dirumuskan apakah pelanggaran tersebut dapat berdampak pada batalnya suatu penetapan tersangka, seperti penggantungan status tersangka yang terlalu lama hingga bertahun-tahun atau terhadap tersangka yang tidak memperoleh bantuan hukum saat dilakukan pemeriksaan.

\section{Daftar Pustaka}

\section{Buku}

Asnawi, M. Natsir, Hermeneutika Putusan Hakim, Cetakan Pertama, UII Press, Yogyakarta, 2014.

Hadin, Ahmad Fikri, Penelitian Hukum Indonesia Kontemporer, Cetakan Pertama, Genta Publishing, Yogyakarta, 2012.

Mertokusumo, Sudikno, Mengenal Hukum Suatu Pengantar, Liberty, Yogyakarta, 2008.

Penemuan Hukum Sebuah Pengantar, Cetakan Kelima, Universitas Atmajaya, Yogyakarta, 2010.

Moerad, Pontang, Pembentukan Hukum melalui Putusan Pengadilan dalam Perkara Pidana, Alumni, Bandung, 2005.

Mulyadi, Lilik, Hukum Pidana Adat Kajian Asas, Teori, Norma, Praktik dan Prosedur, Alumni, Bandung, 2015.

Pradjonggo, Tjandra Sridjaja, Sifat Melawan Hukum dalam Tindak Pidana Korupsi, Cetakan Pertama, Jakarta Lawyer Club, Surabaya, 2010.

Saebani, Beni Ahmad, Metode Penelitian Hukum, Pustaka Setia, Bandung, 2008. 
Sidharta, Bernard Arief, Refleksi tentang Struktur Ilmu Hukum, Mandar Maju, Bandung, 2009.

Sutiyoso, Bambang, Metode Penemuan Hukum Upaya Mewujudkan Hukum yang Pasti dan Berkeadilan, UII Press, Yogyakarta, 2006.

Suwasta, Asep Dedi, Tafsir Hukum Positif Indonesia, Ali Publishing, Bandung, 2011.

Jurnal

Alkostar, Artidjo, "Dimensi Kebenaran dalam Putusan Pengadilan", Varia Peradilan, Edisi No. 281 Ke-XXIV, April 2009.

Asyrof, H.A. Mukhsin, "Asas-Asas Penemuan Hukum dan Penciptaan Hukum oleh Hakim dalam Proses Peradilan", Varia Peradilan, Edisi No. 252 Ke-XXI, November 2006.

Manan, Bagir, "Hakim Sebagai Pembaharu Hukum", Varia Peradilan, Edisi No. 254 Ke-XXII, Januari 2007.

Manan, Bagir, "Judicial Precedent dan Stare Decisis Sebagai Pengenalan", Varia Peradilan, Edisi No. 347 Ke-XXX, Oktober 2014.

Wibowo, Basuki Rekso, "Pembaruan Hukum yang Berwajah Keadilan", Varia Peradilan, Edisi No. 313 Ke-XXVII, Desember 2011.

\section{Internet}

Hiariej, Eddy O.S., Modul Pengantar Hukum Acara Pidana, dalam http:/ / repository. ut.ac.id/4124/1/HKUM4406-M1.pdf, Akses 3 Februari 2017.

Huda, Miftakhul, "Ius Curia Novit", dalam http://www.miftakhulhuda.com/ 2011/02/ius-curia-novit.html, Akses 20 Januari 2017.

Pejovic, Caslav, "Civil Law And Common Law: Two Different Paths Leading To The Same Goal", dalam http://www.victoria.ac.nz/law/research/ publications/about-nzacl/publications/nzacl-yearbooks/yearbook-6,2000/Pejovic.pdf, Akses 20 Januari 2017.

Tawang, Dian Andriawan Dg dan Novina Sri Indiharti, Analisis Yuridis Terhadap Asas Ius Curia Novit dalam Hukum Acara Perdata, Laporan Penelitian Fakultas Hukum Universitas Trisakti Tahun 2001, hlm. 5. dalam http://portal.kopertis3.or.id/bitstream/123456789/1874/1/Analisis Yuridis Terhadap Asas Ius Curia Novit dalam Hukum Acara Perdata.Pdf, Akses 22 Januari 2017. 